Área Abierta. Revista de comunicación

audiovisual y publicitaria

ISSN: 2530-7592 / ISSNe: 1578-8393

EDICIONES

http://dx.doi.org/10.5209/ARAB.58754

\title{
Tras la cámara: estudios sobre mujeres fotógrafas
}

Presentación: Francisco José García-Ramos y Uta Felten

Durante el mes de abril de 2017, el Departamento de Comunicación Audiovisual y Publicidad I de la Facultad de Ciencias de la Información de la Universidad Complutense de Madrid volvió a demostrar su compromiso por la fotografía dando apoyo, por cuarto año consecutivo, a la celebración de un gran encuentro académico desde el cual seguir historiando, debatiendo y reflexionando sobre el hecho fotográfico desde sus orígenes hasta la actualidad. En esta ocasión, la apuesta fue la celebración de un Congreso Internacional sobre Fotografía con la intención de contribuir a la visibilización del papel de la mujer fotógrafa en aras de fomentar una construcción historiográfica, estética y pedagógica más completa, crítica e igualitaria de una práctica profesional y artística que, por otro lado, históricamente ha estado dominada y acaparada por la presencia y el relato de los hombres.

Gracias a la inestimable ayuda de Laia Falcón Díaz-Aguado y María José Revuelta Bayod, directoras del congreso junto a Francisco José García-Ramos, Fotógrafas: mujeres tras la cámara (Investigación, Estética y Prácticas Pedagógicas), abrió sus puertas como un espacio marco desde el cual trabajar en relatos y discursos sobre la fotografía, desde una perspectiva amplia y diversa en sus temáticas y posibles enfoques pero donde la mujer, tanto como profesional o amateur de la fotografía, fuese siempre la única protagonista. La amplitud de líneas de investigación, comunicaciones, propuestas y experiencias compartidas de manos de fotógrafas como Marga Clarck, Ouka Leele, Isabel Muñoz, Concha Casajús, Pilar Pequeño, Quintina Valero, Marisa Martil, Miren Pastor, Arantza Aramburu-Hamel, Sara Zorraquino, Mara Stacca, Mar Sáez y Evangelina Esparza convirtió este encuentro en un apasionante espacio de trabajo. Un lugar desde el que seguir generando inercias que consigan abrir fisuras y que la mujer adquiera un justo protagonismo en los relatos académicos sobre la historia y la práctica de la fotografía.

Será, precisamente, esta misma pasión y lucha compartida la que llevó a Alfonso Puyal Sanz, director de Área Abierta a brindarnos la oportunidad de trabajar en un monográfico que desarrollase algunas de las líneas de investigación puestas en común en este congreso internacional. Una invitación por la que no podemos más que reiterar nuestro agradecimiento y enfatizar el apoyo e impulso de una iniciativa como esta, en la que una revista académica especializada en comunicación audiovisual y publicidad vuelve a ofrecer un monográfico para tratar con amplitud cuestiones desde un enfoque de género. El resultado de este compromiso se materializa ahora en este número. Algo que, por otro lado, tampoco hubiera sido posible sin la colaboración de la Universidad de Leipzig (Alemania) con la ayuda y apoyo incondicional de Uta Felten. 
Así, y bajo el título Tras la cámara: estudios sobre mujeres fotógrafas, el presente volumen monográfico se articula a través de nueve aportaciones llevadas a cabo por diez investigadoras y un investigador procedentes de varias universidades españolas (Universidad Complutense de Madrid, Universidad de Burgos, Universidad ESNECamilo José Cela y Universidad Internacional de La Rioja) y extranjeras (Universität Leipzig, Alemania) además de jóvenes investigadoras independientes. Así hemos tratado de reflejar trabajos con diferentes metodologías, marcos teóricos y enfoques que, a la vez, reflejen variedad en la procedencia de las autoras, instituciones de origen y posición dentro de la carrera académica universitaria.

Conscientes de que todo acto de selección implica, a su vez, un acto de exclusión y que el espacio siempre es demasiado limitado para dar cabida a tantas investigadoras, fotógrafas y creadoras que merecían estar aquí presentes, este monográfico no se plantea como algo cerrado y finito. Todo lo contrario. Se presenta como una cartografía en proceso, un espacio en construcción por el que seguir transitando y haciendo camino.

El recorrido que planteamos comienza con una serie de propuestas de carácter historiográfico que reflexionan sobre el papel y presencia de las mujeres en el ámbito de los estudios fotográficos del siglo XIX, en las principales agencias de prensa creadas a largo del siglo XX y en la industria del cine español durante el franquismo. Será el caso de Stéphany Onfray en Ellas: de modelo a fotógrafa. La mujer como impulsora de nuevas formas retratísticas en los estudios fotográficos madrileños (1860-1880), María Peralta Barrios en El desafio de las fotoperiodistas. Una aproximación a la presencia de mujeres en las agencias fotográficas y Francisco José García-Ramos en El cine desde la cámara de una pionera del fotoperiodismo español: los proyectos de Juana Biarnés como foto-fija en Cataluña (1956-1963).

Este itinerario por la historia y práctica fotográfica llevada a cabo por mujeres continuará a través de la obra de una amplia selección de creadoras que, durante el siglo XX, han utilizado la fotografía documental como recurso artístico para investigar la realidad de su entorno público y privado. Un deambular entre espacios donde se fotografía la vida y se articula la subjetividad al que nos invita $\mathrm{M}^{\mathrm{a}}$. Dolores Clemente-Fernández, Nieves Febrer-Fernández, $\mathrm{M}^{\mathrm{a}}$. del Mar Martínez-Oña en La fotografía documental como recurso en la obra de mujeres artistas: de la flâneuse a la cronista de realidades inventadas. Un trabajo que da paso y contextualiza tres propuestas de análisis enfocadas a las prácticas de autorrepresentación a través del retrato fotográfico. En este marco, Uta Felten analiza en Feminidades nomádicas en la fotografía del siglo $X X$ las estrategias subversivas y contradiscursivas del nomadismo como lugar común en la creación de mujeres artistas. Desde espacios más próximos a la praxis artística, Noelia Báscones Reina en Mujer, autorretrato y discurso autobiográfico. Revisión del autorretrato fotográfico en la obra de mujeres artistas abordará la obra de algunas de las principales mujeres artistas del siglo XX y XXI que han utilizando el autorretrato fotográfico como medio de expresión y reivindicación del yo. Por su parte, Ana Quiroga Álvarez en The Body which is Truly Ours. A Brief Three-Stage Approach to Mass Society through Photography analizará el papel de las mujeres como objetos y sujetos de deseo en la cultura occidental a través de sus autorretratos.

La última parada de este monográfico se plantea a modo de casos específicos de estudio donde se abordan en profundidad los trabajos fotográficos de Dina Goldstein y Chantal Akerman. Vendrán de manos de Ana Vicens Poveda en La fotografía de 
Dina Goldstein frente al universo rosa: un análisis de las series In The Dollhouse y Fallen Princesses y, finalmente, de Ana González Casero en Atlas fotográfico Akerman: una aproximación a Maniac Shadows de Chantal Akerman como proyecto de autobiografia visual.

Quisiéramos agradecer a todas aquellas personas que, con su aliento y energía, posibilitan la creación de encuentros y publicaciones que sirven como espacio de reflexión sobre la fotografía desde un enfoque de género. Gracias también a Raúl Eguizábal Maza y a todo el equipo de profesoras y profesores del área de fotografía del Departamento de Comunicación Audiovisual y Publicidad I, a Francisco A. Zurián, Investigador Principal del Grupo de Investigación Validado Complutense GECA (Género, Estética y Cultura Audiovisual) y a los grupos P.E. de I+D+i, MINECO, Ref.: HAR2014-53871-P y P.I. AICO/2017/123 por su constante apoyo y ayuda. Y gracias, una vez más, a todo el equipo editorial de Área Abierta por haber aceptado y haber hecho posible nuestra propuesta de monográfico.

Febrero de 2018 